\title{
REMEDIAL MEASURES FOR IMMOBOLIZATION OF HEAVY METALS FROM CONTAMINATED SOIL
}

\author{
Baby Sharma and Mukesh Kumar Chettri* \\ Department of Botany \\ Amrit Science Campus, Tribhuvan University, Kathmandu, Nepal \\ *Email: mukeshkchettri@gmail.com
}

\begin{abstract}
To understand the remedial measures of heavy metals from contaminated soil, three vegetable (Brassica juncea, Brassica rapa and Lepidium sativum) were grown on soil artificially contaminated with $300 \mathrm{mg} \mathrm{kg}^{-1} \mathrm{CuCl}_{2}, 500 \mathrm{mg} \mathrm{kg}^{-1} \mathrm{~Pb}\left(\mathrm{NO}_{3}\right)_{2}, 800 \mathrm{mg} \mathrm{kg}^{-1} \mathrm{ZnCl}_{2}$ or their mixed metal $(1600 \mathrm{mg} \mathrm{kg}$ ${ }^{1}$ ). This experiment showed that $\mathrm{Cu}$ and $\mathrm{Pb}$ accumulation in vegetables are higher in lime treatments than in $20 \%$ cowdung treatments. Zinc accumulation increased in B. rapa and L. sativum in both cow dung and lime treatments compared to control. Accumulation of $\mathrm{Cu}, \mathrm{Pb}$ and $\mathrm{Zn}$ from mixed metal treatment was highest in L. sativum (at lime $9 \mathrm{~g} \mathrm{~kg}^{-1}$ for $\mathrm{Cu}$ and $\mathrm{Pb}$, and $20 \%$ cow dung for $\mathrm{Zn}$ ). Morphological changes such as fresh weight, dry weight, shoot length, root length, mostly increased significantly $(\mathrm{P} \leq 0.01)$ with $\mathrm{Zn}$ and cow dung treatment, but none with lime treatment. Fresh and dry weight increased only in L. sativum grown in $3 \mathrm{~g} \mathrm{~kg}^{-1}$ lime treatment. Immobilization of $\mathrm{Cu}, \mathrm{Pb}$ and $\mathrm{Zn}$ in both single and mixed treatments was found to be high in cow dung amended soil. From this it can be ascertained that $20 \%$ cow dung treatment is suitable for immobilization of supplied heavy metals than lime treatments.
\end{abstract}

Key words: Vegetables, heavy metals, remedial measures.

\section{INTRODUCTION}

The continuous increase of non-degradable toxic heavy metals in the environment emitted via anthropogenic activities like emissions, household waste, sewage sludge, pesticides and fertilizers are major global problems (Nriagu and Pacyna 1988, Goyer 1997, Sharma and Chettri 2005). These ultimately contribute to the deposition of heavy metals on soil of urban and sub urban area and may create dangerous situation on human health. From the contaminated soil heavy metals can enter in human body directly trough inhalation of dusty air of the city (EPA 1976) and ingestion of food, i.e. through edible plants/animals coming from such contaminated fields. Heavy metal contaminated soils reduce plant species richness (Whitton 1970, McLean 1975, Kuiper 1981, Rygg 1985) and increase biologically inactive land via destroying soil quality (McGrath et al. 2001).

Although various phytoextraction works by using plants have been conducted to reduce heavy metal content from contaminated soils (Baker 1981, Legittimo et al. 1995, Ebbs and Kocchian 1998), Batch and column tests for the development 
of an immobilization technology was studied for toxic heavy metals $(\mathrm{Cu}, \mathrm{Ni}$ and $\mathrm{Pb})$ in contaminated soils of closed mines (Jang et al. 1998).

From the study of biomonitoring of heavy metals in vegetables and their dietary intake estimation via vegetables (Sharma and Chettri 2004, 2005), it is observed that there is high accumulation of heavy metals ( $\mathrm{Pb}$ and $\mathrm{Cd}$ ) in soil and vegetables of Kathmandu valley as compared to normal plant value of Bowen, 1979. Heavy metal contaminated soil will certainly hamper production of vegetables and will invite toxicological problems among the human and animal health through food chain. Therefore, to reduce this problem, a suitable approach has been investigated in the present study.

The availability of heavy metal present in soil can be changed into the insoluble and benign forms (such as hydroxides and sulphides compounds) (Arocha et al. 1996). In agricultural fields, soil pH decreases with the use of chemical fertilizers like ammonium sulfate and diammonium phosphates, urea, etc (Brady and Well 2004). Therefore, in the present study some easily available and ecofriendly, organic material like cow dung and inorganic materials like agricultural lime were selected. It is hypothesized that organic matter like cow-dung in the soil will increase organic acids (like humic acid and fulvic acids) and proteins which will provide binding sites to excess heavy metal ions in the soil and this will reduce heavy metal accumulation in vegetable crops. Similarly, inorganic material agricultural lime was selected because the acidic soil is neutralized by it. Generally, toxic metals are available to plants under low $\mathrm{pH}$ condition, but addition of agricultural lime will increase soil $\mathrm{pH}$ to neutral or slightly alkaline condition. Therefore, It is hypothesized that adding agricultural lime will reduce heavy metal accumulation in vegetable crops.

\section{MATERIALS AND METHODS}

Sandy loam soil (3.5 kg per bag) were artificially contaminated each with $300 \mathrm{mg} \mathrm{kg}^{-1}$ $\mathrm{CuCl}_{2} / 500 \mathrm{mg} \mathrm{kg}^{-1} \mathrm{~Pb}\left(\mathrm{NO}_{3}\right)_{2} / 800 \mathrm{mg} \mathrm{kg}^{-1} \mathrm{ZnCl}_{2} /$ or their mixed concentration ( $=1600 \mathrm{mg} \mathrm{kg}^{-1}$ soil). All experiments were conducted in polyethylene bags and were designed in such a manner to understand the accumulation of $\mathrm{Cu}, \mathrm{Pb}$ and $\mathrm{Zn}$ in vegetables after the uses of (I) cow dung as organic manure and (II) lime as inorganic treatments. All treatments were in triplicates and were arranged in randomized block design. The seeds of $B$. juncea L. (Broad leaf mustard), B. rapa L. (Turnip) and $L$. sativum L. (Pepper Cress) were collected from reliable seed store - Annapurna Biz Bhandar, Ason, Kathmandu. Artificially heavy metal contaminated soil were amended with cow-dung (5 and $20 \%$ ) or agricultural lime (3 $\mathrm{g}$ and $9 \mathrm{~g} \mathrm{~kg}^{-1}$ soil) and control for each treatment was set without cow-dung or lime treatment. Vegetable crops grown were harvested after 5 weeks. The harvested crops were cleaned thoroughly with tap water and finally washed with de-ionized water. Fresh weight (FW) was measured for individual plants (after half hour of washing) which were then oven dried at temperature of $60^{\circ}-70^{\circ} \mathrm{C}$ for $48 \mathrm{~h}$ to $72 \mathrm{~h}$ to obtain the constant dry weight (DW) after air dried. Root length (RL) and SL were measured to study the effect of cow dung or lime. Ultimately a representative samples were prepared for the digestion process. Metal analysis of the representative samples were done after wet digestion according to Chettri et al. (1997). Metal $(\mathrm{Cu}, \mathrm{Pb}$ and $\mathrm{Zn})$ content in the filtrate was analyzed using Atomic Absorption Spectrometry (AAS) with their respective wavelength (Welz 1985). For each treatment, triplicate samples were tested. Two plant materials of NBS standards (National Bureau of Standards, USA) with Nos. 1573 (Tomato leaves) and 1575 (Pine needles) were also analyzed, following the same procedure and the metal recoveries ranged from 94 to 99 
percent. Each soil sample was also analyzed for $\mathrm{CU}, \mathrm{Pb}$ and $\mathrm{Zn}$, following the same procedure. To understand the significant difference in growth parameters like FW, DW, DW\% RL and SL, after growing on soil contaminated with single and mixed metals amended with cow dung or lime, data were statistically analyzed using One-way Anova followed by Duncan's multiple range test (with the help of SPSS 12.0 version).

\section{RESULTS}

Accumulation of $\mathrm{Cu}, \mathrm{Pb}$ and $\mathrm{Zn}$ in B. juncea, L. sativum and B. rapa, tested for their remedial measures by using cow dung and lime are presented in Fig. 1 A-C (from single metal treatments) and in Fig. 2 (from mixed metal treatments). Copper accumulation in $B$. juncea, $L$. sativum and $B$. rapa (grown on $300 \mathrm{mg} \mathrm{CuCl}_{2} \mathrm{~kg}^{-1}$ soil) was higher in lime (both 3 and $9 \mathrm{~g} \mathrm{~kg}^{-1}$ treatments) than in cow-dung treatments. $B$. juncea and B. rapa showed highest accumulation of $\mathrm{Cu}$ in low dose of lime $\left(3 \mathrm{~g} \mathrm{~kg}^{-1}\right)$, but $L$. sativum showed high accumulation in high dose of lime $\left(9 \mathrm{~g} \mathrm{~kg}^{-1}\right)$. Lowest accumulation of $\mathrm{Cu}$ was observed at $20 \%$ cow-dung in all vegetables (Fig. 1A). Lead accumulation (from $500 \mathrm{mg} \mathrm{Pb}\left(\mathrm{NO}_{3}\right)_{2} \mathrm{~kg}^{-1}$ soil) in L. sativum was significantly high in $9 \mathrm{~g}$ lime treatment than in both control and $3 \mathrm{~g}$ lime treatment (Fig. 1B). Lead accumulation in B. rapa also increased slightly in both 3 and $9 \mathrm{~g} \mathrm{~kg}^{-1}$ lime treatments. No significant changes have been observed in B. juncea treated with both doses of lime than in control. Lowest accumulation of $\mathrm{Pb}$ was recorded in all vegetables grown on soil amended with $20 \%$ cow dung (Fig. 1B). Zinc accumulation (from $800 \mathrm{mg} \mathrm{ZnCl} \mathrm{kg}^{-1}$ soil) in $B$. rapa and $L$. sativum was increased in both cowdung and lime treatment than in control, but in $B$. juncea it decreased in both treatments than in control (Fig. 1C).
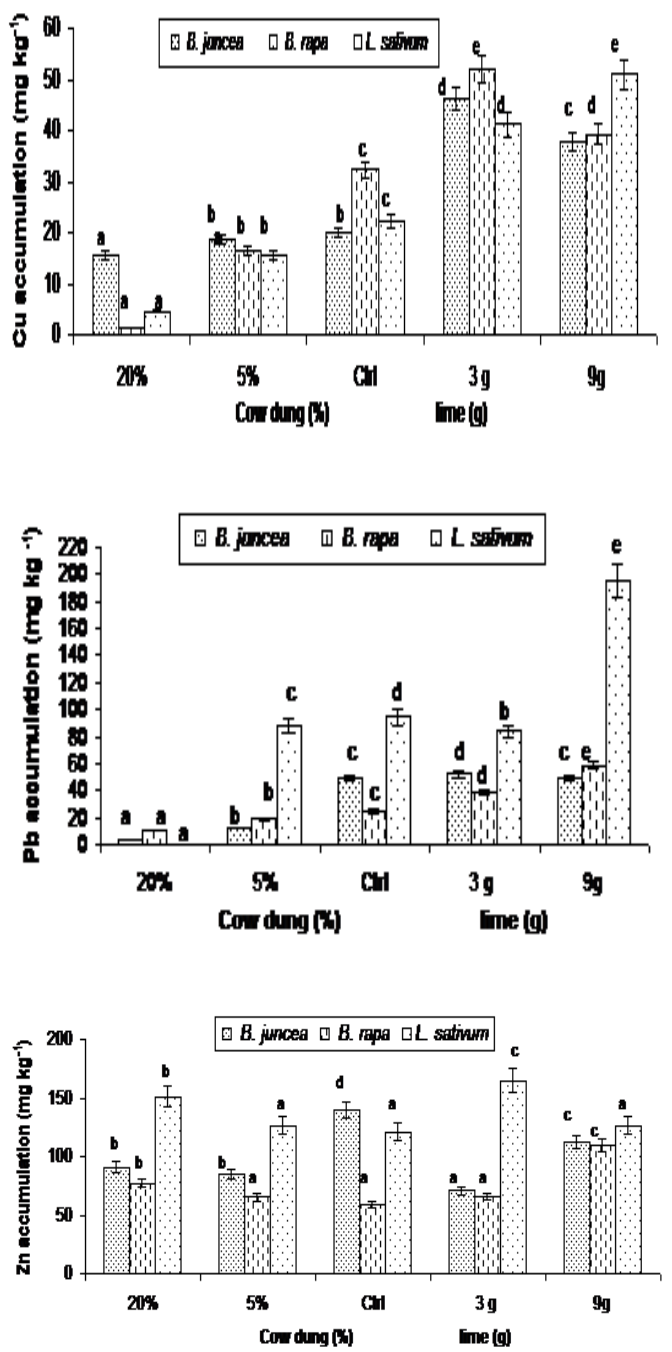

Fig. 1 A-C. Accumulation of $\mathrm{Cu}, \mathrm{Pb}$ and $\mathrm{Zn}$ in vegetables grown on soil treated with $\mathrm{CuCl}_{2}$ $\mathrm{Pb}\left(\mathrm{NO}_{3}\right)_{2}$ and $\mathrm{ZnCl}_{2}$ respectively; and cow-dung or lime. Different letters on the bar of each treatment of a crop denote significant differences obtained from ANOVA followed by Duncan's multiple range test (at $P=0.05$ )

Accumulation of $\mathrm{Cu}, \mathrm{Pb}$ and $\mathrm{Zn}$ (from mixed metal $1600(\mathrm{Cu}+\mathrm{Pb}+\mathrm{Zn}) \mathrm{mg} \mathrm{kg}^{-1}$ soil $)$ was highest in $3 \mathrm{~g}$ lime in $B$. juncea than in control or other treatments (Fig. 2 A-C). Lowest accumulation of $\mathrm{Pb}$ was observed in $B$. juncea and $L$. sativum grown on 5 and $20 \%$ cow-dung. $\mathrm{Zn}$ accumulation 
in L. sativum was quite high in $20 \%$ cow-dung treatment. Accumulation of $\mathrm{Pb}$ and $\mathrm{Zn}$ in $B$. rapa were mostly reduced in cow dung treatment compared to control but the plant could not grow in lime treated soil.
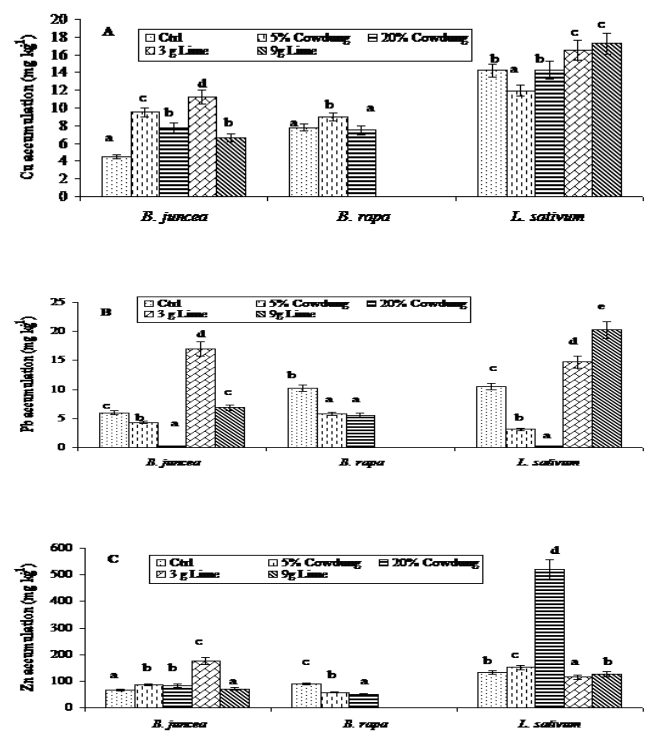

Fig. 2 A-C. Accumulation of $\mathrm{Cu}(\mathrm{A}), \mathrm{Pb}(\mathrm{B})$ and $\mathrm{Zn}(\mathrm{C})$ in vegetable crops grown on soil treated with mixed metals $\left(\mathrm{CuCl}_{2}+\mathrm{Pb}\left(\mathrm{NO}_{3}\right)_{2}+\mathrm{ZnCl}_{2}\right)$ along with cow-dung or lime. Different letters on the bar of each treatment of a crop denote significant differences obtained from ANOVA followed by Duncan's multiple range test (at $P$ $=\mathbf{0 . 0 5})$

Morphological parameters such as FW, RL and SL increased in all tested vegetable grown on $\mathrm{CuCl}_{2}$ treated and cow-dung amended soil but $\mathrm{FW}$, DW, RL and SL decreased in all the cases of $\mathrm{CuCl}_{2}$ treated and lime amended soil (Fig. 3A).

Fresh weight and SL increased significantly $(\mathrm{P}<0.05)$ in $B$. juncea and B. rapa, and $\mathrm{RL}$ increased significantly $(\mathrm{P}<0.05)$ in $L$. sativum grown on $20 \%$ cow-dung amended and $\mathrm{Pb}$ treated soil. Shoot length, FW, DW decreased in all grown on $\mathrm{Pb}$-treated and lime amended soil (Figs. 3B)
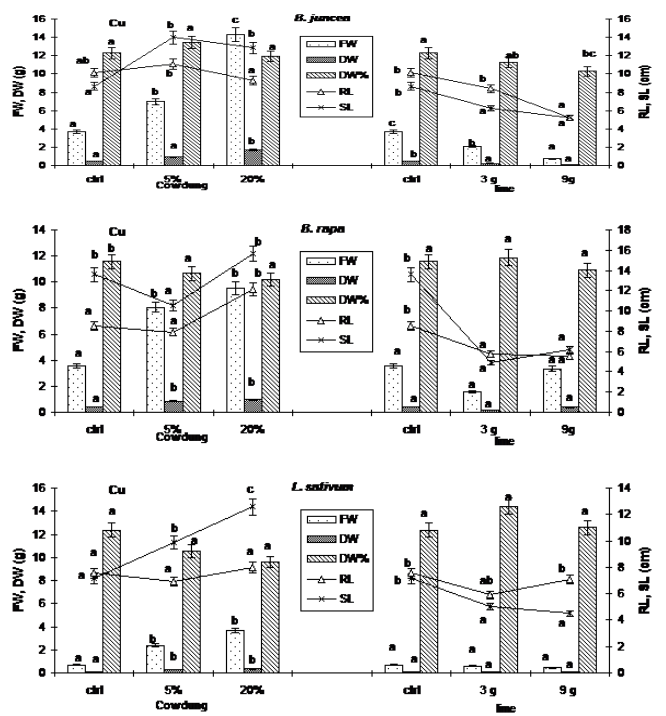

Fig. 3A. Fresh weight, DW, DW\%, RL and SL of the vegetables grown on soil treated with $\mathrm{CuCl}_{2}$ and cowdung or lime. Different letters on the bar of each treatment of a crop denote significant differences obtained from ANOVA followed by Duncan's multiple range test (at $P=0.05$ )
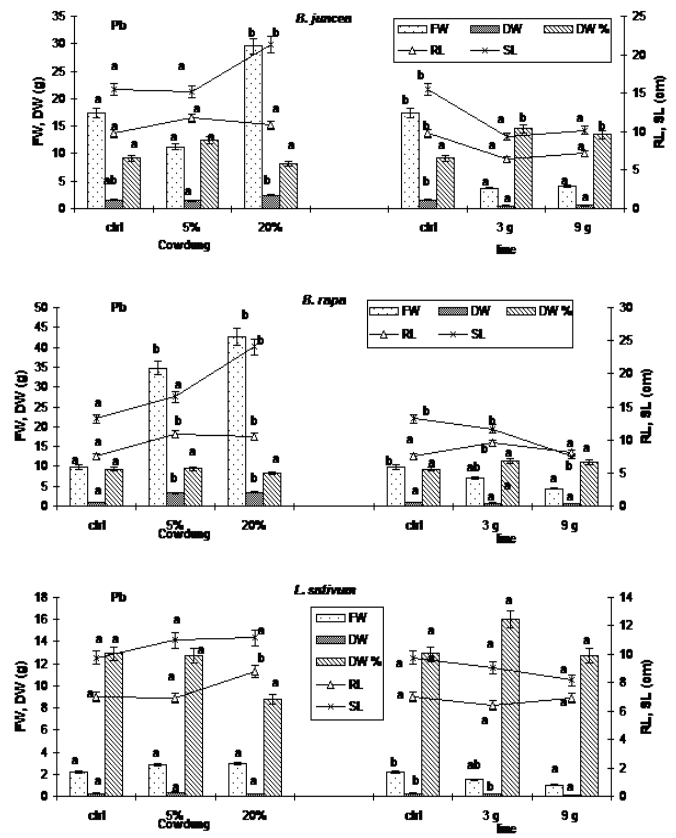

Fig. 3B. Fresh weight, DW, DW\%, RL and SL of the vegetables grown on soil treated with $\mathrm{Pb}\left(\mathrm{NO}_{3}\right)_{2}$ and cow-dung or lime. Different letters on the bar of each treatment of a crop denote significant differences obtained from ANOVA followed by Duncan's multiple range test (at $P=0.05$ )

ECOPRINT VOL 19, 2012 
Fresh weight, DW, SL and RL (except RL in B. rapa) increased significantly $(\mathrm{P}<0.01)$ in all vegetables grown on cow-dung amended and $\mathrm{Zn}$ treated soil, but no significant changes were observed with lime treatments (Figs. 3C). Fresh weight and DW increased only in L. sativum grown in $3 \mathrm{~g}$ lime treatment, whereas DW\% increased significantly in $B$. rapa of both the doses of lime.
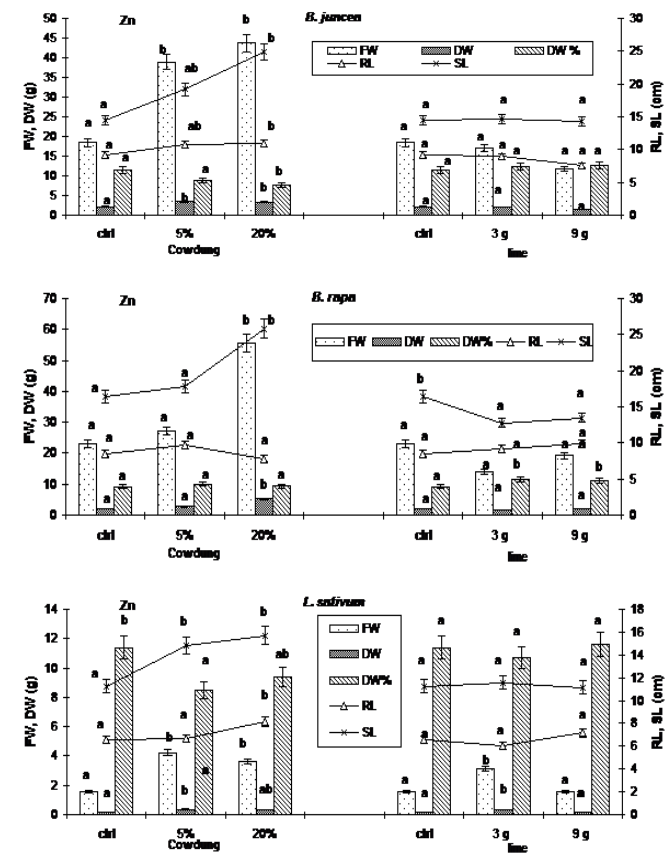

Fig. 3C. Fresh weight, DW, DW\%, RL and SL of the vegetables grown on soil treated with $\mathrm{ZnCl}_{2}$ and cow-dung or lime. Different letters on the bar of each treatment of a crop denote significant differences obtained from ANOVA followed by Duncan's multiple range test (at $P$ $=0.05$ )

In vegetables grown on mixed metal treated soil and amended with cow-dung, SL and FW in $B$. juncea increased significantly; FW and DW in $L$. sativa increased significantly; and SL, RL, FW and DW in B. rapa, increased significantly (Fig. 3D). Vegetables grown on mixed metal and lime amended soil showed changes in RL, FW and DW, all of which decreased significantly but DW\% increased significantly than in control. In $L$. sativum, only DW\% increased significantly in lime amended conditions. Brassica rapa could not grow in lime amended soil.

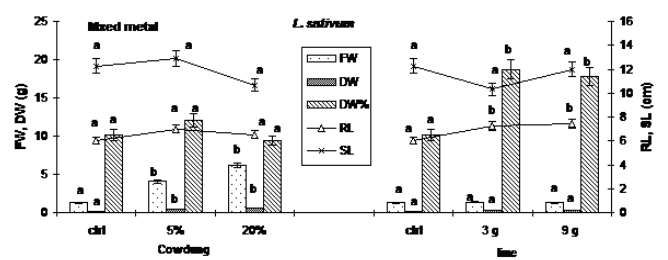

Fig. 3D. Fresh weight, DW, DW\%, RL and SL of the vegetables grown on soil treated with mixed metals and cow-dung or lime. Different letters on the bar of each treatment of a crop denote significant differences obtained from ANOVA followed by Duncan's multiple range test (at $P=0.05$ )

Soil $\mathrm{pH}$ of the soil (treated with heavy metals as single metal or their mixed metal) increased both with cow dung (at 5\% and 20\%) and lime (at 3 and $9 \mathrm{~g} \mathrm{~kg}^{-1}$ soil) treatments. Soil $\mathrm{pH}$ was comparatively higher in cow-dung treatments than in lime treatments. Soil $\mathrm{pH}$ ranged from 6.12 to 6.49 in control condition, but it increased with $5 \%$ and $20 \%$ cow dung treatments and ranged from 7.53 to 7.86 and from 8.07 to 8.28 , respectively.

Immobilization of each supplied heavy metals such as $\mathrm{Cu}, \mathrm{Pb}$ and $\mathrm{Zn}$ in both single and mixed metal treatments were found to be high in cowdung amended soil (Fig.4). It indicated that cowdung helps in retaining toxic metals in the soil and reduces its mobilization to the plant body. But in soil treated with single metal salts such as $\mathrm{CuCl}_{2}$ and $\mathrm{Pb}\left(\mathrm{NO}_{3}\right)_{2}$ with lime amendment, $\mathrm{Cu}$ and $\mathrm{Pb}$ retained in the soil were lower than in control, indicating their free mobility in the plants. In mixed metal treatments, immobilization of $\mathrm{Cu}, \mathrm{Pb}$ and $\mathrm{Zn}$ mostly increased in both cow-dung and lime treatments. From this it can be ascertained that $20 \%$ cow-dung treatment is suitable for immobilization of supplied metals than lime treatments (Fig. 4). 


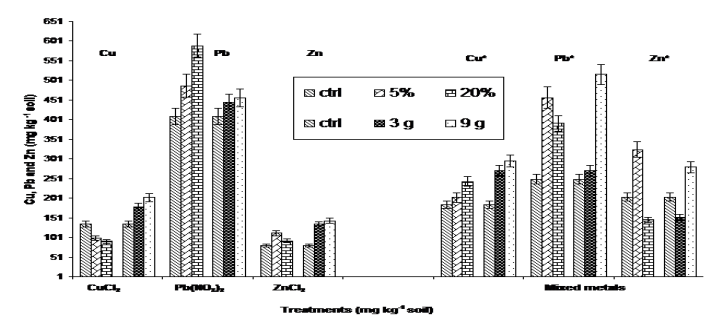

Fig. 4. Concentration of $\mathrm{Cu}, \mathrm{Pb}$ and $\mathrm{Zn}$ in soil treated with single and mixed metals with different quantities of cow dung (\%) or lime (g). (*indicate metals retained in mixed metal treated soil).

\section{DISCUSSION}

In the present study, the accumulation of toxic metals was low and FW was higher in most cases in cow dung amended soil than in lime amended soil, although the soil $\mathrm{pH}$ was increased more in cow dung amended soil. This may be due to sorption of toxic heavy metal by the protein, carbohydrate and phenolic compounds (Friedmann and Waiss 1972) contained in cow dung. These compounds have metal binding functional group such as carboxyl, hydroxyl and amino groups. Besides this, the presence of cation exchange capacity in cow-dung would have played the roles in the nutrient balance via supply of essential macronutrients (NPK) and micronutrients (Fe, Mn, $\mathrm{Cu}, \mathrm{B}$ etc). The increased $\mathrm{DW}$ in increased soil $\mathrm{pH}$ via the addition of cow dung treatment may indicate the availability of essential nutrient in exchangeable fractions by the organic portions of the cow dung in one hand and the binding of excess of toxic metals in other side by the functional group. At high $\mathrm{pH}$ most of the $\mathrm{Pb}$ is retained in the hydroxide and carbonate phase (Yong et al. 1993).

Most of the vegetables grown on lime amended soil showed significant decrease in FW, DW and SL, indicating loss in yield. In lime treatments of $9 \mathrm{~g} \mathrm{~kg}^{-1}$ soil, accumulation of $\mathrm{Pb}, \mathrm{Cu}$ and $\mathrm{Zn}$ increased in most vegetables. This is possibly due to unavailability of essential nutrient ions on one hand (Scotti et al. 1999) and availability of excessive supplied toxic ions in increased soil $\mathrm{pH}$ condition, which must have hampered their growth. The supplied lime $\left(\mathrm{CaCO}_{3}\right)$ probably regulated the root permeability (Jacobson et al. 1961) and possibly maintained the integrity of the cell structure (like cell membrane, cell wall). This probably helped in binding more toxic metals than in control condition.

Vegetable crops grown on soil with single metal treatment amended with cow dung showed increased FW, DW, RL and SL. This may be due to availability of moisture and nutrient from the organic material on one hand and unavailability of toxic metals to plants on the other hand. The supplied heavy metals in the soil may get bind with humic acid, fulvic acids and proteins present in the cow dung (Akio et al. 1993) and form complexes (Benes et al. 1976, Stevenson 1976, Cole 1977). Metals bound in humic acids are often difficult to remove and even in very sandy soils extraction can require vigorous procedures (Hodgson 1963).

The percent amount of each representative chemical species of metals differs not only according to $\mathrm{pH}$, but also according to available ligands in soils solutions. The important characteristics are the stability constants of complexes in the soil and the plant system, and are determined by the ligand type (i.e. the matrix in soil and/or plant like humic acid, fulvic acids, simple organic acids, and organic materials in general) as well as $\mathrm{pH}$ and ionic strength (Streit and Stumm 1993). Typical ligands in soil solutions contain the carboxyl groups which are formic, acetic, oxalic and citric acid. Organic ligands that contain nitrogen or sulfur in the soil solution is the amino acids. A great variety of different ligands partners include those derived from the benzene ring to which carboxyl (to form benzene carboxylic acids) or hydroxyl groups (to form phenolic groups) are attached. Actually the majority of 
heavy metals in the soil system will usually be absorbed to some surface and not found in free solution, except at an excess of solved chelating agents (Streit and Stumm 1993).

Soil $\mathrm{pH}$ in lime amended soil is 7.6 to 7.9 , which are mostly higher than in control (6.8-7.6). Generally, the availability of metals for uptake by plants is greater at low $\mathrm{pH}$ than at high $\mathrm{pH}$ (Sims 1986) and the net effect of an increase in soil $\mathrm{pH}$ value by liming of soil for example is a reduction in metal adsorption by plants (Davis and Coker 1980). As the organic matter was not provided in lime amended soil, there would be low available binding sites for soil heavy metal. So due to this reason the supplied heavy metals were easily available to plants.

\section{CONCLUSIONS}

From the experiments of remedial approaches it can be concluded that cow dung provides ligands for binding heavy metals and reduced availability of dominant cations for the plant uptake. Therefore, cow dung treatment may have resulted good productivity than in the lime treatments. Cow dung (10-20\% by weight) is recommended to use in orders to reduce heavy metal uptake in the vegetables when grown on contaminated soil. Lime alone is not recommended for the immobilization of heavy metals.

\section{ACKNOWLEDGEMENTS}

Authors acknowledge thanks to the Head of Botany Department for providing space and work facilities in the Research laboreatory of Department of Botany, Amrit Campus, Lainchour, Kathmandu.

\section{REFERENCES}

Akio, S., M. Nobufumi and U. Yosio. 1993. Effects of heavy application of fresh cow dung on to the humus composition of an Ando soil, Southern Kyusyu. Bulletin of the Faculty of Agriculture, Kagoshima University 43:1-10.
Arocha, M.A. 1996. Voc immobilization in soil by adsorption, absorption and encapsulation. J. of Hazardous Materials 51:131-149.

Baker, A.J.M. 1981. Accumulators and excludersstrategies in the response of plants to heavy metals. J. Plant Nutr. 3:643-654.

Benes, P., E.T. Gjessing and E. Steinnes. 1976. Interactions between humus and trace elements in fresh water. Water Res. 10:711-716.

Bowen, H.J.M. 1979. Environmental Chemistry of the Element. Academic Press, London.

Brady, N.C. and R.R. Well. 2004. The Nature and Properties of Soils, $13^{\text {th }}$ edition. Pearson education (Singapore) Pte, Ltd.

Chettri, M.K., T. Sawidis and S. Karataglis. 1997. Lichens as a tool for biogeochemical prospecting. Ecotox. Environ. Safety 38(1):322-335.

Cole, M. 1977. Lead inhibition of enzyme synthesis in soil. Applied Environ. Microbial. 33:262-268.

Davis, R.D. and E.G. Coker. 1980. Cadmium in agriculture with special reference to the utilization of sewage sludge on land. Technical Report TR 139. WRC Medmenham, Marlow.

Ebbs, S.D. and L.V. Kochian. 1998. Phytoexcration of zinc by oat (Avena sativa), barley (Hordeum vulgare) and Indian mustard (Brassica juncea). Environ. Sci and Technol. 32:802-806.

Environmental Protection Act (EPA). 1976. EPA 68-02-1344, EPA RES. Triangle Park. North Carolina.

Friedman, M. and A.C. Waiss. 1972. Mercury uptake by selected agricultural products and by-products. Environ. Sci. Technol. 6:457458.

Goyer, R.A .1997. Toxic and essential metal interactions. Annu. Rev. Biochem 17:37-50.

Hodgson, J.F. 1963. Chemistry of the micronutrient elements in soils. Adv. Agron. 15:119-159. 
Jacobson, L., R.J. Hannapel, M. Schaedle and D.P. Moore. 1961. Effects of root to solution ratio in ion absorption experiments. Plant Pysiol. 36:62-65.

Jang, A., Y.S. Choi and I.S. Kim. 1998. Batch and column tests for the development of an immobilization technology for toxic heavy metals in contaminated soils of closed mines. PII: S0273-1223(98)00237-6. Water Sci. 37(8):81-88.

Kuiper, J. 1981. Fate and effects of cadmium in marine plankton communities in experiments enclosures. Mar. Ecol. Prog. Ser. 6:161-174.

Legittimo, P.C., L. Ducceschi and M. Martini. 1995. Plant species as indicators of geochemical anomalies: Experiences on Hex aquifolium (holly). Environ. Geol. (Berlin) 25:114-118.

McGrath, S.P., F. Jhao and E. Lombi. 2001. Plant and rhizosphere processes involved in metal contaminated soil. Plant and Soil 232:207214.

McLean, R.O. 1975. Zinc tolerance of Hormidium rivulare Kutz. Br. Phycol. J. 10:313.

Nriagu, J.O. and J.M. Pacyna. 1988. Quantitative assessment of worldwide contamination of air, water and soils by trace metals. Nature 333:134-139.

Rygg, B. 1985. Effect of sediment copper on benthic fauna. Mar. Ecol. Prog. Ser. 25:83-89.

Scotti, A.I., S. Silva and G. Botteschi. 1999. Effects of fly ash on the availability of $\mathrm{Zn}, \mathrm{Cu}$, $\mathrm{Ni}$ and Cd to chicory. Agriculture, Ecosystem, and Environ. 72:159-163.
Sharma, B. and M.K. Chettri. 2004. Dietary Intake of trace elements via vegetables grown in Kathmandu valley. Proceedings of $I V$ conferences on Sci. and Technol. Nepal Academy of Science and Technology, March, 23-26. 1:980-988.

Sharma, B. and M.K. Chettri. 2005. Monitoring of heavy metals in vegetables and soil of agricultural fields of Kathmandu valley. Ecoprint 12:1-9.

Sims, J.T. 1986. Soil pH effects on the distribution and plant availability of manganese, copper and zinc. Soil Sci. Soc. Am. J. 50:367-373.

Stevenson, F.J. 1976. Binding of metal ions by humic acids. In: Environmental Biogeochemistry. (ed.) Nriagu, J.O. Ann. Arbor Sci. Ann. Arbor Mich. 2:519-540.

Streit, B. and W. Stumm. 1993. Chemical properties of metals and the process of bioaccumulation in terrestrial plants. In: Plants as Biomonitors-indicators for Heavy Metals in the Terrestrial Environment. (ed.) Markert, B. VCH, Weinheim. New York. Basel, Cambridge, pp. 415-424.

Welz, B. 1985. Atomic Absorption Spectrometry. $\mathrm{VCH}$, Weinheim, Germany.

Whitton, B.A. 1970. Toxicity of heavy metals to freshwater algae. A review: Phykos. 9:116125.

Yong, R.N., R. Galvez-Cloutier and Y. Phadungchewit. 1993. Selective sequential extraction analysis of heavy metal retention in soil. Canadian Geotechnical J. 30:834-847. 